\title{
地下鉄を考慮した 名古屋と大阪の大規模浸水解析
}

\author{
村瀬将隆 1 ・中島勇介 2 ・武田 誠 $3 \cdot$ 川池健司 4 ・松尾直規 5 \\ 1 学生会員 中部大学大学院工学研究科建設工学専攻（†487-8501 愛知県春日井市松本町 1200） \\ E-mail: tc15015-9664@sti.chubu.ac.jp \\ 2 学生会員 中部大学工学部都市建設工学科（广487-8501 愛知県春日井市松本町 1200) \\ 3 正会員 博士(工学) 中部大学教授 工学部都市建設工学科（ $\bar{T} 487-8501$ 愛知県春日井市松本町 1200) \\ E-mail: mtakeda@isc.chubu.ac.jp \\ 4 正会員 博士(工学) 京都大学准教授 防災研究所（テ612-8235 京都市伏見区横大路下三栖東ノ口） \\ 5フェロー 工学博士 中部大学教授 工学部都市建設工学科（广487-8501 愛知県春日井市松本町 1200）
}

\begin{abstract}
近年，東日本大震災による津波災害や，平成 27 年の鬼怒川破堤による洪水災害など，大規模な浸水災 害が生じている．地下鉄や地下街など高度に地下空間が活用されている都市域に対して大規模な浸水災害 が生ずれば，その氾濫形態は複雑化することが考えられ，地下空間の浸水被害のみでは無く，地下鉄の線 路が新たな水路となり，他地域一の浸水を広めることも考えられる. 本研究は, 名古屋と大阪の地下鉄を 有する都市域を対象に，洪水破堤による大規模な浸水解析を行い，地下鉄の有無による浸水被害の違いや 地域による浸水特性を明らかにする.
\end{abstract}

Key Words: Urban inundation analysis, Undergournd space, Subway, Nagoya, Osaka

\section{1. はじめに}

近年，地球温暖化による異常気象や大型台風により豪 雨災害が増加している．平成 27 年には，台風 18 号の大 雨により鬼怒川で洪水が発生し，堤防決壊により，常総 市，結城市，筑西市，下妻市，つくばみらい市の $5 つ の ~$ 市に及ぶ大規模浸水が生じた. また，平成 23 年には名 古屋市の側を流れる庄内川でも大きな洪水が発生し, 名 古屋市民の 100 万人に対して避難勧告が発令された. こ のとき, 志段味地区における越水被害は生じたものの, 幸いにも破堤とそれに伴う大規模浸水は生じていない. 仮に，大規模な浸水が生ずれば，高度に発展した地下空 間施設（地下街および地下鉄）を有する名古屋市では, その地下空間へ汇濫水が流入し，甚大な被害を引き起こ すことが容易に想像できる．したがって，地下空間を有 する都市域において, 大規模浸水を対象に解析を行い, その浸水特性を予め把握寸ることは, 減災や危機管理の 面功も非常に重要と考える.

近年，地下空間の浸水に着目した研究が精力的に実施 されている，そのなかで，地下鉄に関わる研究事例を挙

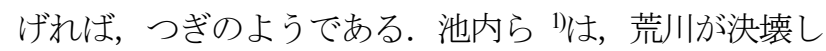
た場合の地上部と地下鉄などの浸水状況の把握を目的と
し，地下鉄などの出入口およびトンネルにおける止水板, 防水扉を反映した詳細な解析モデルを構築し, 浸水状況 とその対策を検討している. 関根ら 2)は都市内の道路市 ットワーク，下水道および河川を対象に豪雨による内水 汇濫解析を実施し，汇濫水の地下鉄への流入の可能性と 地下鉄内の浸水域桩大過程を検討している，岡部ら 》は 淀川の洪水破堤を考慮し，大阪の海老江処理区に流入し た汇濫水の地下鉄への流入とそこから地下鉄内を伝播す る氾濫水について検討を行っている.

著者らも名古屋を対象に洪水破堤に伴う地下街・地下 鉄を考慮した都市の浸水解析を実施し，その成果をまと めている ${ }^{4), 5)}$. 著者らが開発したモデルは, 河川洪水流 を一次元不定流解析で, 汇濫水の挙動をデカルト座標系 の平面二次元不定流解析で表現し，地下街および地下鉄 駅を一つのボックスとしてとらえ，地下鉄の線路におけ る水の挙動をスロットモデルを考慮した一次元不定流解 析で表現している. これらのデータの多くは Web 上で 入手可能であり，汎用性の高い解析ツールとなっている. 地下空間を含めた都市の浸水状況は与えられる外力と 共に地盤高分布や地下空間の位置が大きく影響するもの と考えられる. そこで, 本研究では, 本解析モデルを名 古屋と大阪に適用し, 洪水破堤に伴う大規模浸水の様子 
を明らかにするとともに，両者の比較を行うことで地形 や地盤高分布の違いによる浸水の特徵を明らかにする.

名古屋の研究事例は, 既に武田・西田ら5によって報 告されているが，ここでは，計算条件を再度設定し，大 阪との比較のために浸水特性を簡潔にまとめている.

\section{2. 解析の概要}

\section{（1）洪水氾濫解析}

本研究では, 武田・西田ら ${ }^{5)}$ が開発した洪水汇濫解析 モデルを使用し，河川の洪水流には 1 次元不定流モデル を, 都市域の氾濫域にはデカルト座標の平面 2 次元不定 流モデルを，地下鉄線路の流れにはスロットモデルによ る 1 次元不定流モデルを適用し，地下街・地下鉄駅を 1 つのボックスとして連続式を考慮した水理計算を行って いる. また，河川と汇濫格子の間の堤防では越流現象を 考慮し, 水位が堤防高よりも高い状況下では自動的に越 流が計算される，庄内川および淀川では $200 \mathrm{~m}$ ，都市域 では $50 \mathrm{~m}$ ，地下鉄線路は $50 \mathrm{~m}$ 程度の格子幅の計算格子を 設定し, 小河川は汇濫域の非計算格子として扱っている.

\section{（2）計算領域および条件}

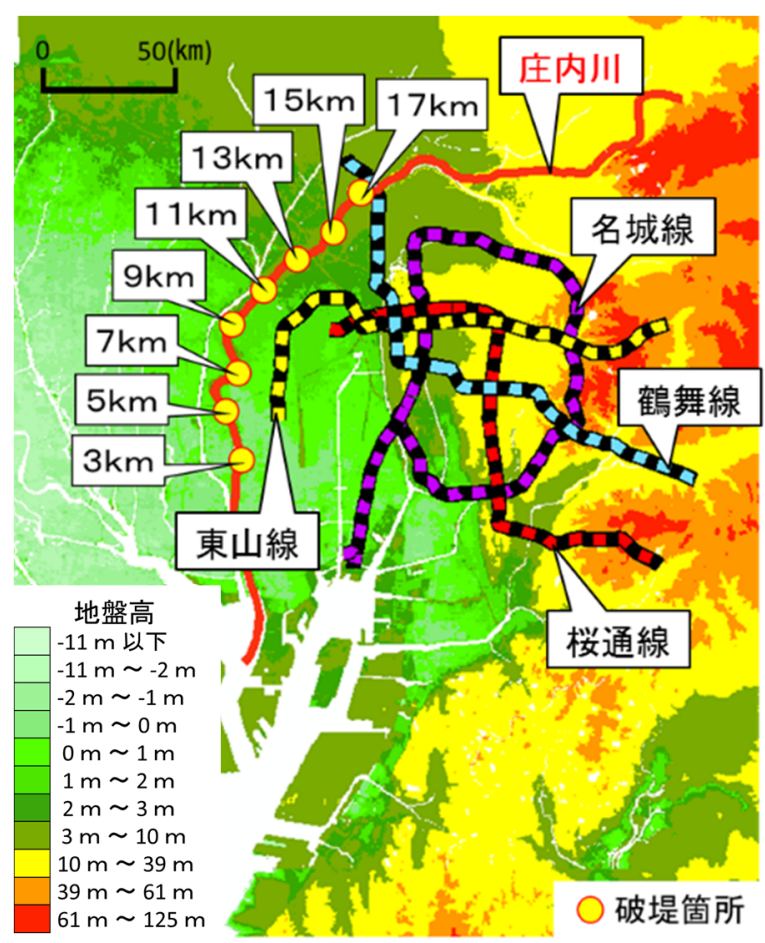

図-1 名古屋の計算領域

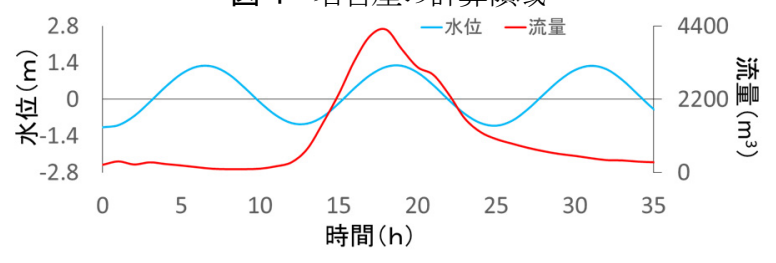

図-3 庄内川の下流端水位と流量ハイドログラフ (a) 計算領域と破堤条件

名古屋と大阪の計算領域をそれぞれ図-1，図-2 に示寸. 名古屋の計算では, 河口から $3 \mathrm{~km} \sim 17 \mathrm{~km}$ まで, 大阪の 計算では, 河口から $3 \mathrm{~km} \sim 15 \mathrm{~km}$ までを $2 \mathrm{~km}$ 毎に $100 \mathrm{~m}$ 幅 で破堤（破堤箇所の堤防天端が堤内地の地盤高に置き換 わる）させた想定破堤汇濫解析を実施した.

\section{(b) 計算条件}

境界条件の流量と水位を図-3 と図-4 に示寸. 名古屋 の解析では, 庄内川の上流端に, 計画高水流量を基にピ 一ク值が $4400 \mathrm{~m}^{3} / \mathrm{s}$ となる流量を与え, 河川の下流端には 破堤時間に満潮となる大潮の水位を与えた. 破堤は計算 開始 19 時間後に行い，計算時間は 36 時間とした. 一方， 大阪の解析では, 淀川の上流端流量に, 計画高水流量を 基にピーク值が $12000 \mathrm{~m} / \mathrm{s}$ となる流量を与え, 河川の下 流端には破堤時間に満潮となる大潮の水位を与えた。破 堤時間は計算開始 19 時間後，計算時間は 61 時間とした.

(c) 地下街・地下鉄駅と地下鉄線路のモデル化

本研究では，地下街・地下鉄駅の面積，底面高と線路 の線形と高さを整備した. 地下街・地下鉄駅の面積, 線 路の線形はWebにある数值地図を基に整理した．駅にお

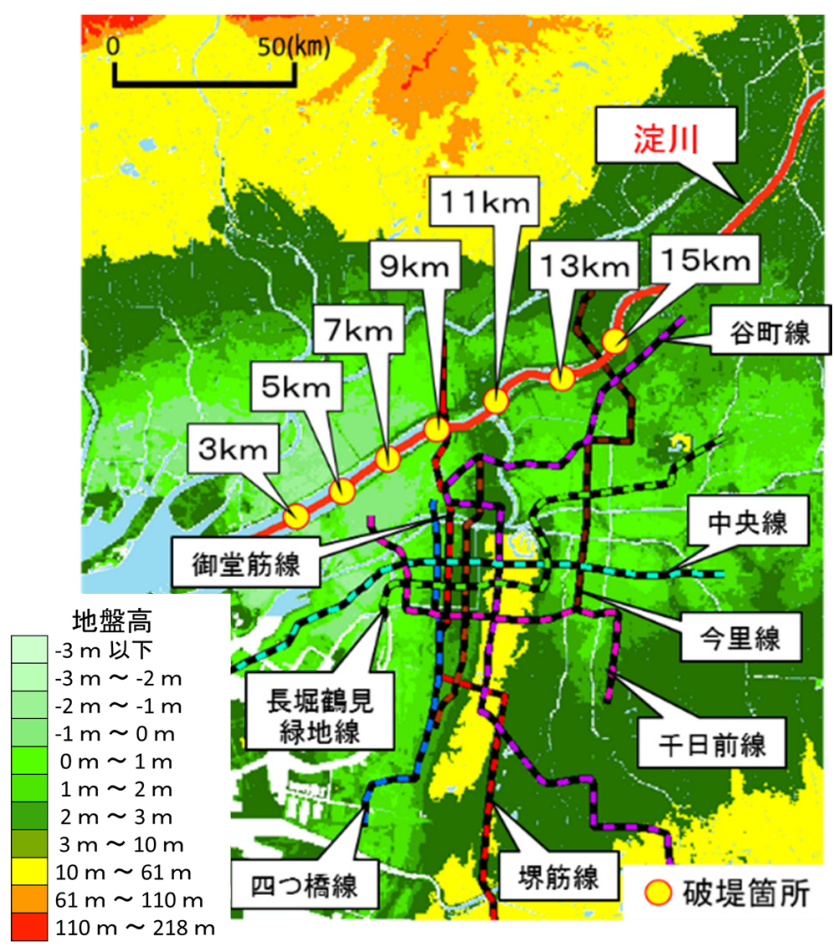

図-2 大阪の計算領域

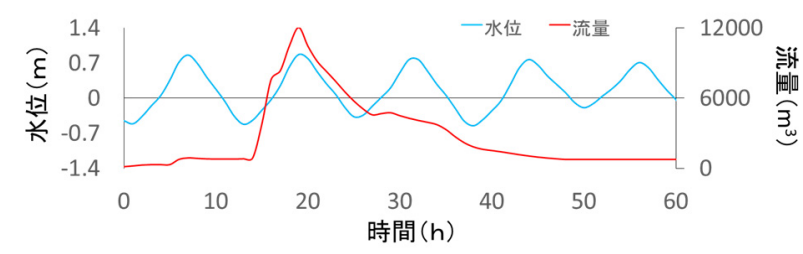

図-4 淀川の下流端水位と流量ハイドログラフ 


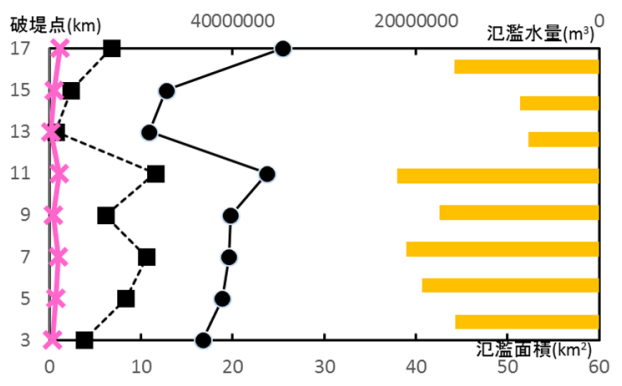

地下鉄を考慮していない場合

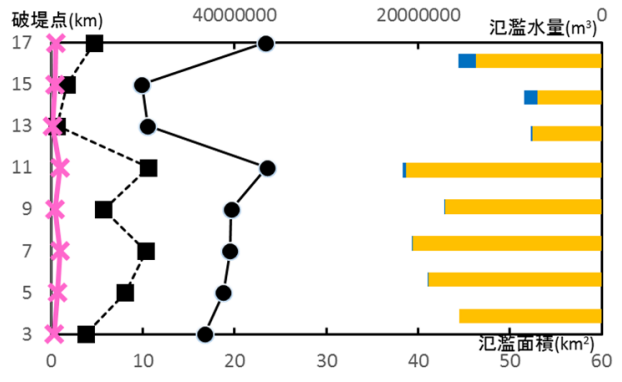

地下鉄を考慮した場合

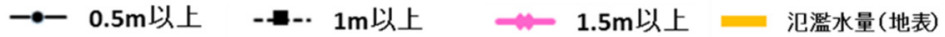

図-5 名古屋の汇濫水量と汇濫面積

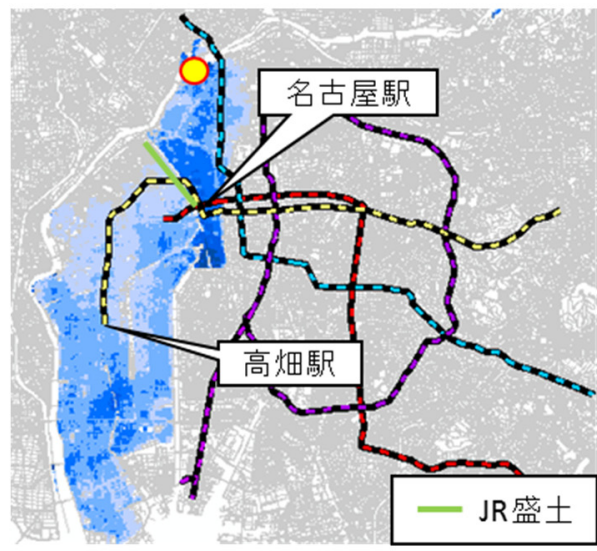

地下鉄を考慮していない場合

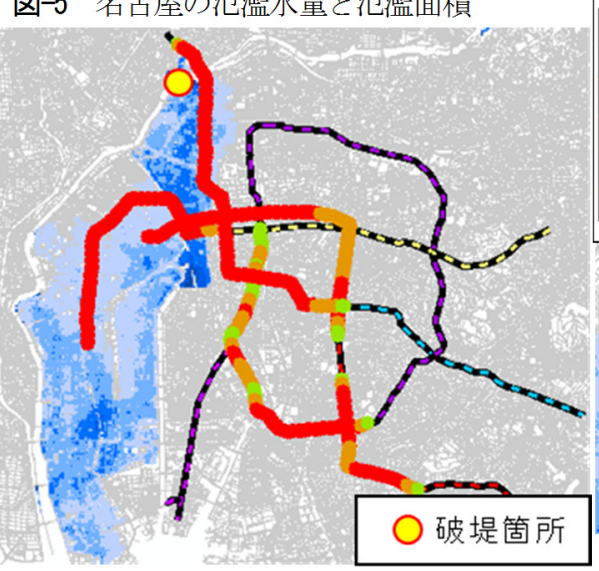

地下鉄を考慮した場合

図-6 名古屋の最大浸水深の分布 ける地下鉄線路高を基礎として，縦 $4.35 \mathrm{~m} \times$ 横7.75m の地 下鉄断面があり，線路の高さは駅の線路高から線形補間 して求めた. 名古屋の地下空間の入口情報は現地調査の 值を用い，大阪の地下空間の入口情報には名古屋の調査 の最頻值（道路から歩道の段差 $(0.15 \mathrm{~m})$, 歩道から地下空 間の入口の段差 $(0.15 \mathrm{~m})$, 横幅 $(4 \mathrm{~m})$ ) を与えた. 名古屋の 地下鉄の各駅の高さに関する情報は，現地調査を行うこ とで入手した。 また，大阪の解析では，線路断面の天井 の上 $0.5 \mathrm{~m}$ に地下街・地下鉄の底面高があると仮定した。 乗換駅では複数の底面高が現れるので，一番高い值を地 下街・地下鉄駅の底面高とし，地下街・地下鉄駅と地下 鉄線路の間には接続箇所があり, その幅の総長を $20 \mathrm{~m}$ と した. なお，本研究では，地上にある入口の止水板およ び地下空間のポンプ排水は考慮していない.

\section{3. 解析結果}

\section{(1) 名古屋の場合}

地下鉄を考慮しない場合と考慮する場合の破堤箇所毎 の名古屋の計算終了時の汇濫水量と最大浸水深を用いた 汇濫面積を図-5 に示す。 まず，図-5 の結果から破堤箇 所において，浸水面積と汇濫水量に違いがあることが分 かる．また，地下鉄を考慮しない場合の氾濫水量は地下 鉄を考慮する場合の地上と地下の総水量と一致している.

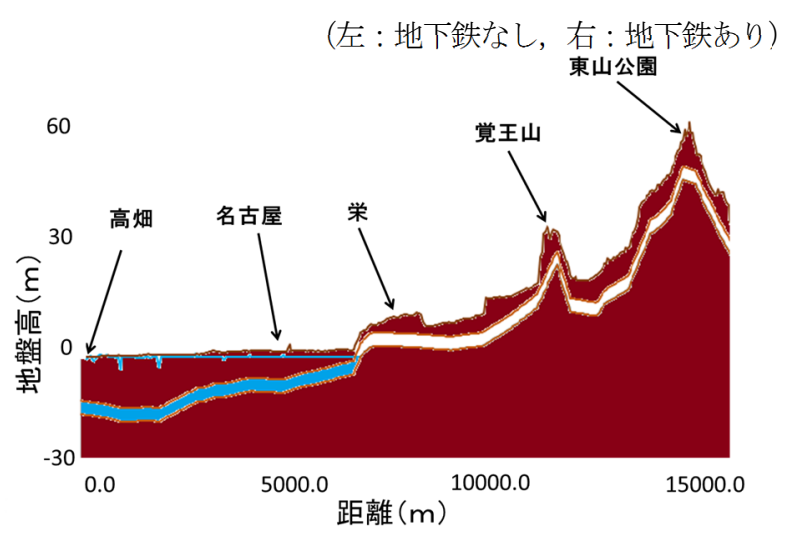

図-8 計算終了時の東山線の縦断面図

このことは，質量保存の観点からの計算モデルの妥当性 を示している。 さらに，図-5 から，庄内川の河口から $15 \mathrm{~km}$ と $17 \mathrm{~km}$ の解析において，地下空間に多くの汇濫水 が流入することが示された，それに伴い，地上の氾濫面 積が減少していることが分かる。これらの破堤箇所は $\mathrm{JR}$ 盛土よりも上流側であり，これらの場所で破堤すれ ば，汇濫水は地下空間の入口が多く存在する名古屋駅前 に集まって流下寸るので，地下空間への流入が多くなる と考えられる. 河口から $3 \mathrm{~km}$ から $13 \mathrm{~km}$ の破堤の場合, 破堤箇所による氾濫面積, 氾濫水量の違いがみられ，地 下空間への流入は少ないことが分かる. $17 \mathrm{~km}$ 破堤にお ける，地下鉄を考慮しない場合と考慮する場合の最大浸 水深の分布を図-6に示す. また, 図-7 は最大浸水深の 


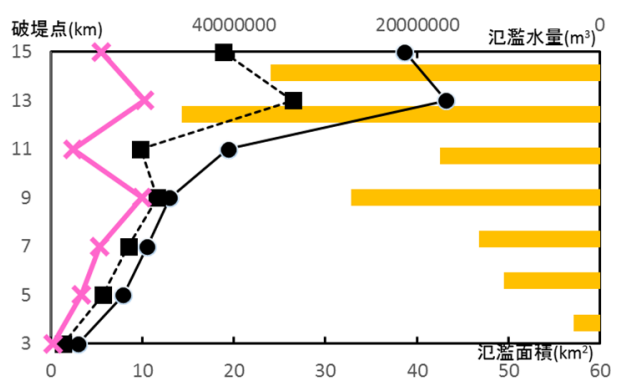

地下鉄を考慮していない場合

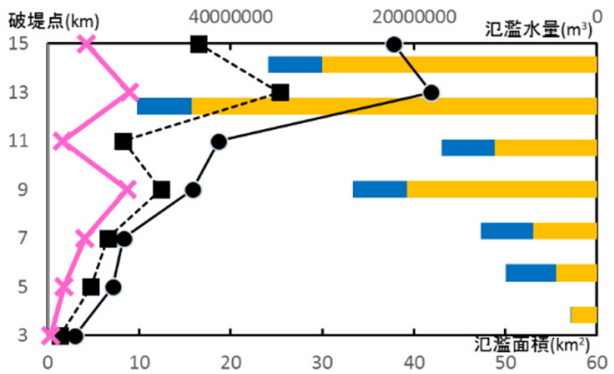

地下鉄を考慮した場合

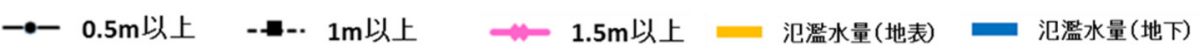

図-9 大阪の氾濫水量

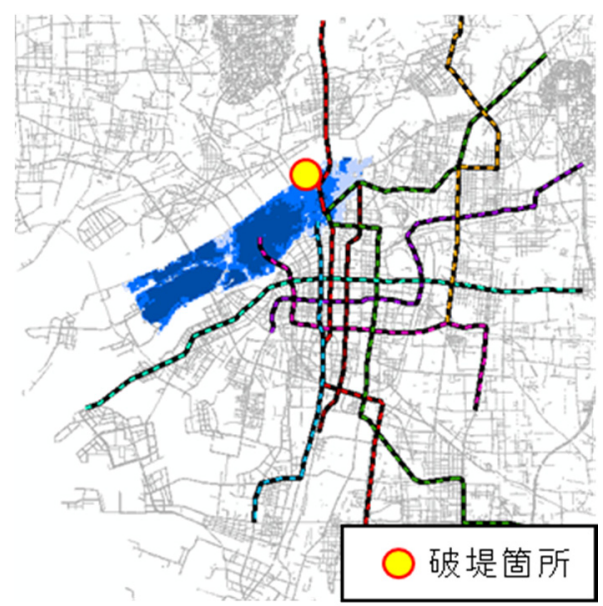

地下鉄を考慮していない場合

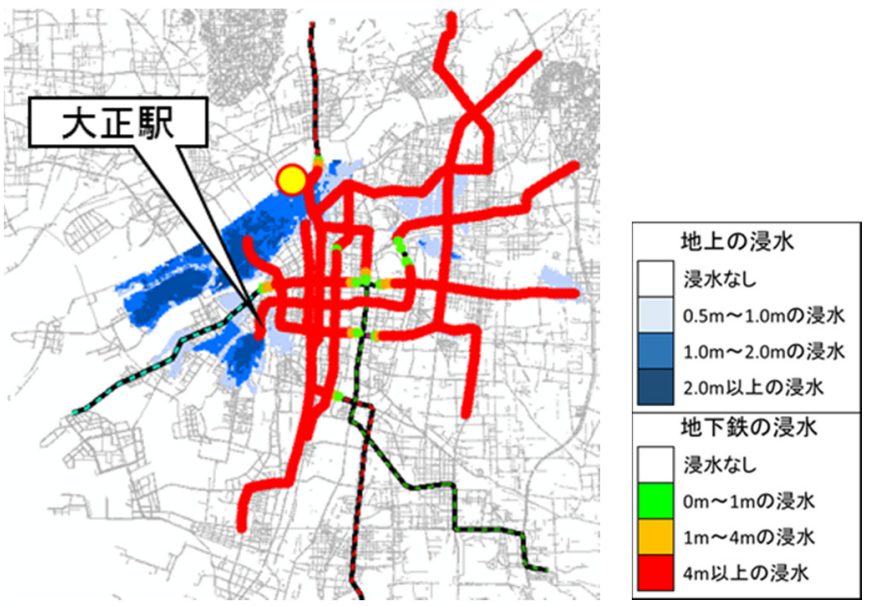

地下鉄を考慮した場合

図-10 大阪の最大浸水深の分布 $(9 \mathrm{~km}$ 地点の破堤の場合)

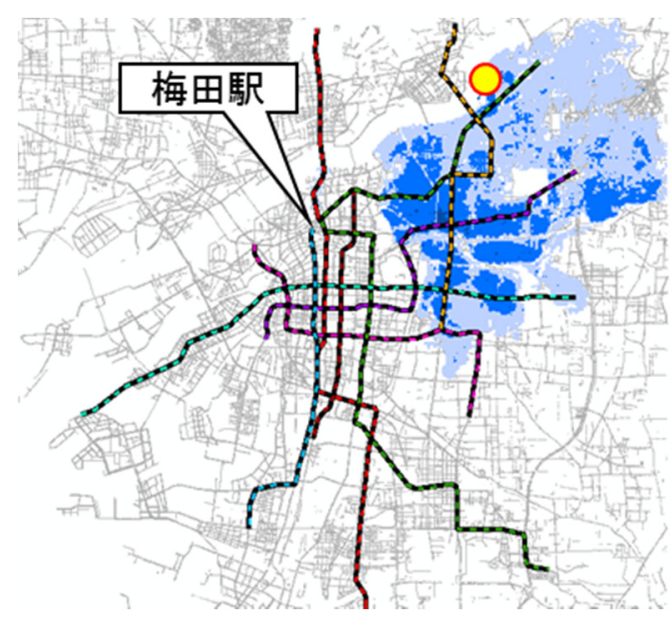

地下鉄を考慮していない場合

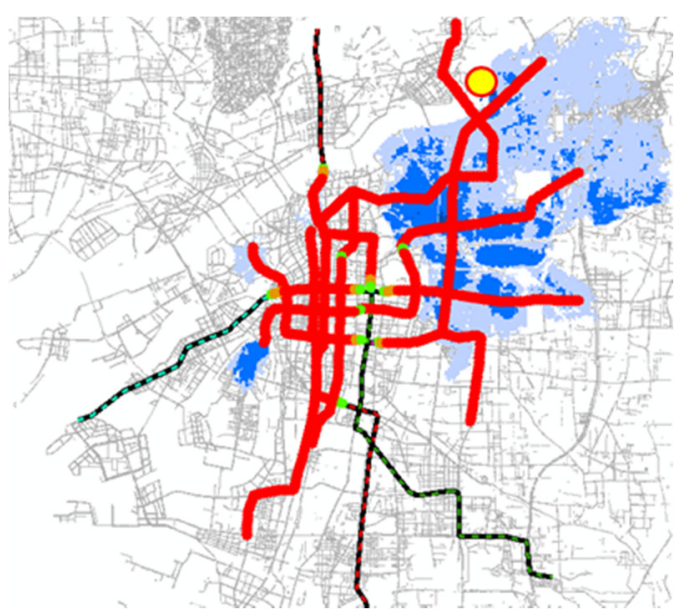

地下鉄を考慮した場合
30

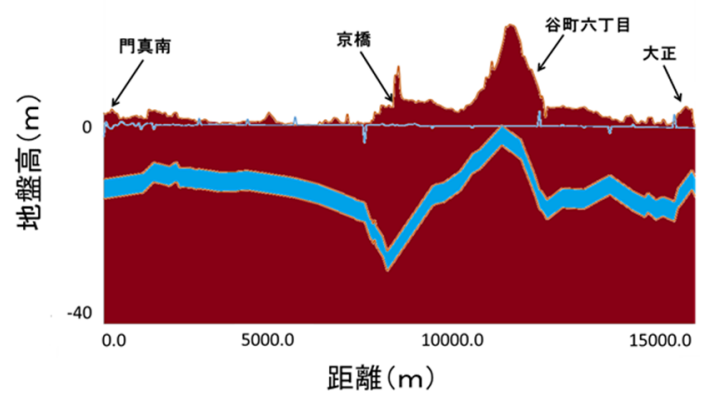

図-12 長堀鶴見緑地線の縦断方向水位(破堤箇所 9km 地点)

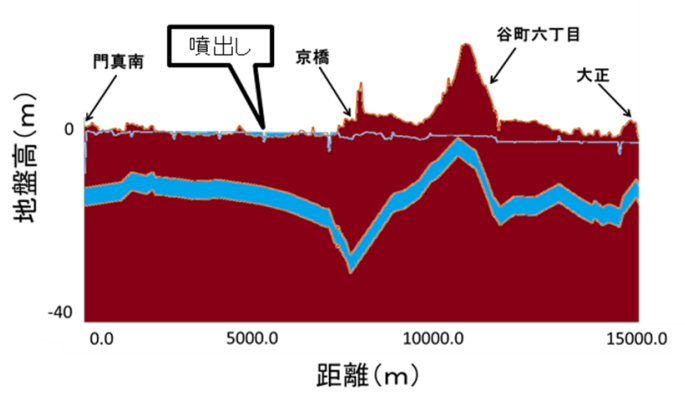

図-13 長堀鶴見緑地線の縦断方向水位(破堤箇所 $15 \mathrm{~km}$ 地点) 
分布に差がみられる場所を拡大したものである．地下鉄 を考慮することで，赤枠で囲われている箇所において最 大浸水深が低くなっていることがわかる. 名古屋の地盤 高は東側が高くなっており，図-6 の結果から庄内川か ら溢れた汇濫水が東方に広がらないことが示された。 ま た，地下鉄も同様に東方の線路高が高くなっており，地 下の浸水も東方に拡がらない. 図-8 は計算終了時の東 山線の縦断面図である. 図-8 の様子からも線路高の高 、地域に水が拡がらないことが分かる．庄内川の河口か ら $17 \mathrm{~km}$ 地点で破堤した場合, 汇濫水は鶴舞線から流入 し，地上からの汇濫水の流入や乗換駅を通じて，他の線 路一広がっている. 名古屋の桜通線は名古屋の地下鉄線 路の中で最も線路高が低いため, 広範囲に浸水が拡がっ ていく様子が示された.

\section{（2）大阪の場合}

地下鉄を考慮しない場合と考慮する場合の，大阪にお ける破堤箇所毎の氾濫水量と汇濫面積を図-9 に示寸.

図-2 に示すように, 大阪の地盤高は全体的に低く, 計 算領域中央の地盤が高くなっている. 図-9 の結果から 大阪の浸水は河口から $3 \mathrm{~km}$ 以外の破堤箇所で大量の汇濫 水が地下一流入しており，地下一の流入水量は破堤箇所 が違ってもほぼ同様であった。 これは，大阪が低平地に 位置しており，地盤の低い地域に地下鉄が建設されてい るためと考えられる.ここで，9km 破堤と $15 \mathrm{~km}$ 破堤の 最大浸水深の分布を図-10, 図-11 に示寸. 図-10 の結果 から，9km 破堤では，小河川域で囲われた梅田駅周辺に 浸水が集中している. 大阪の解析では大川（旧淀川）を 非計算領域としているため, 地上の浸水はその川を跨い で広域に拡がらない.しかし，図-12 と図-13 に示すよ

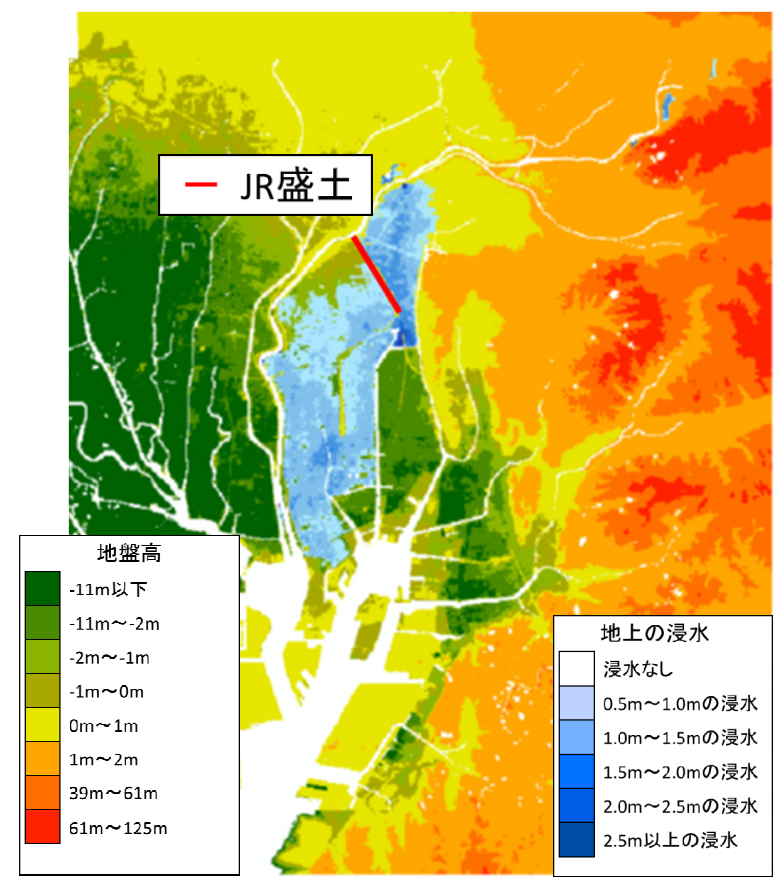

図-14 名古屋の浸水深の分布（17km 地点の破堤）
うに，地下鉄線路を水路として水が流れ，他地域で溢 れることから，地下鉄の有無による浸水の様子に違いが みられた。

\section{（3）名古屋と大阪の浸水特性の比較}

本研究では, 破堤箇所毎の浸水の様子を考察し, 名古 屋では河口から $15 \mathrm{~km}$ や $17 \mathrm{~km}$ の破堤により, 多大な水が 地下空間の入口の多い名古屋駅周辺一流れ込むため, 地 下一流入する流量が多くなり, 地下鉄線路が水没する浸 水が生じている. しかし, 他の破堤箇所では, 浸水深が 小さく, 広く分布することから, 地下空間への多大な

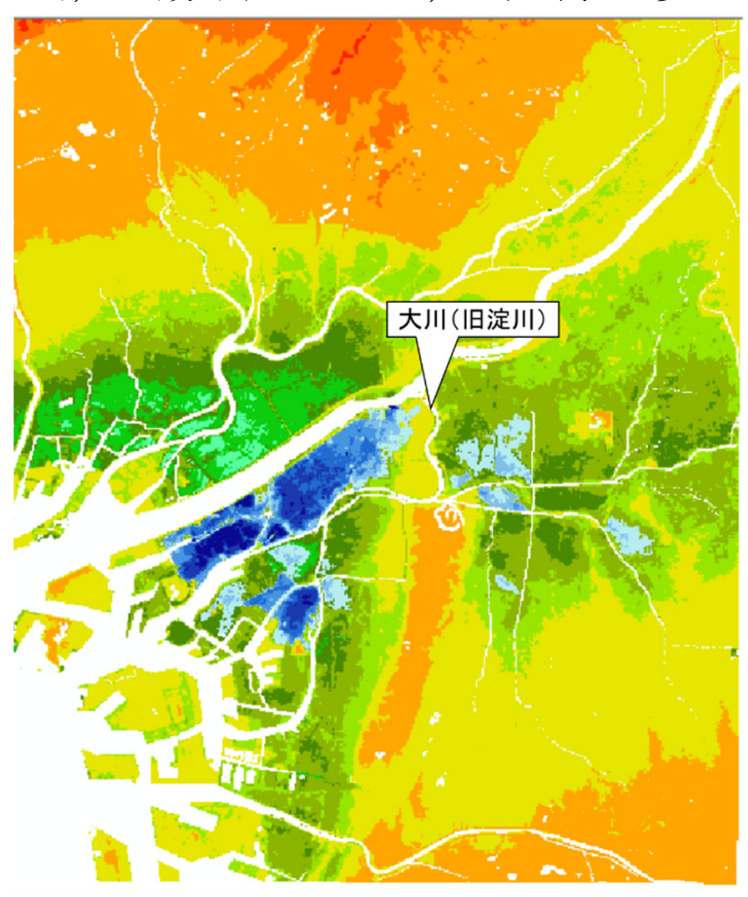

(a) $9 \mathrm{~km}$ 地点の破堤

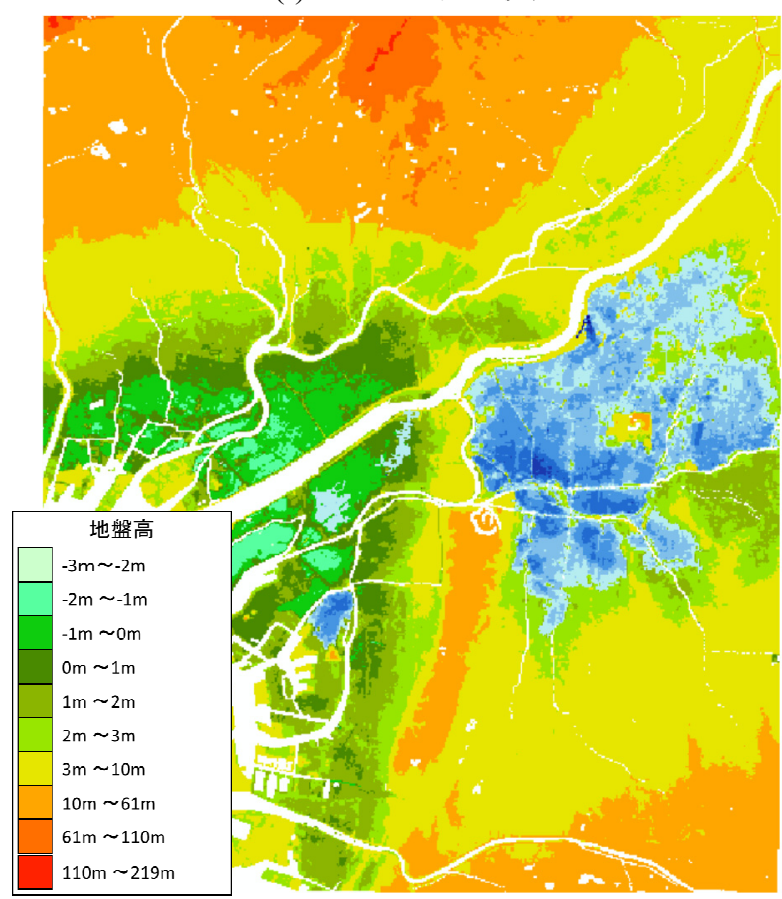

(b) $15 \mathrm{~m}$ 地点の破堤

図-15 大阪の浸水深の分布 
流入は無く, 地下浸水も生じにくいといえる. 一方，大 阪では，低いところに地下空間の入口があり，地下鉄線 路路も地盤高の低い場所を通過している. したがって, ひとたび大規模浸水が生じれば，低い方一流入し，地下 空間の入口で浸水が流入して多大な被害になると共に, 鉄道線路を伝って浸水があふれ出す可能性もあることが 分かった. これは場所（都市）による浸水特性の違いで あり，大阪では破堤に伴う地下浸水について検討寸る必 要性が高いものと考える.

\section{3. おわりに}

本研究では, 武田・西田らにより開発された地下鉄を 有する都市の浸水解析モデルを用い, 名古屋と大阪の洪 水汇濫に適用して大都市の浸水特性を考察した. 本研究 により得られた成果をまとめると以下のようである.

1) 名古屋では，JR盛土よりも上流側の場所で破堤が生 ずれば，汇濫水は名古屋駅前に集まって流下寸るので, 地下空間への流入が多くなる. そのような特徵もあり， 破堤箇所毎の浸水面積, 汇濫水量が異なっている. ただ し, 名古屋は東側が丘陵地であるので, 破堤汇濫による 浸水は東部へは拡がらない.この点は地下鉄の水理でも 同様であり，地下鉄浸水も部分的である.

2) 大阪では，破堤箇所による浸水面積，汇濫水量が異 なることが示されたが，地下空間への汇濫水量の值は破 堤箇所が違ったとしても，ほぼ同じ值となっている．こ れは，大阪は低平地に地下空間が存在するため，洪水氾 濫による汇濫水が多く地下空間へ流入し，鉄道線路も低 い場所を通っているので，広域に浸水が及んでおり，満 水になっているためと考えられる．また，鉄道線路を伝 って水が拡がっており, ある場所では陸上一流出してい ることが示された.
3）前述したように，本研究では名古屋と大阪における 地下鉄を考慮した浸水解析を実施した．本研究により， それぞれの特徵が明らかとなり，特に，大阪における地 下空間の浸水に対する脆弱性が示された.

謝辞 : 本研究は文部科学省委託事業気候変動リスク情報 創生プログラム「課題対応型の精密な影響評価」のもと で行われたことを記す。

\section{参考文献}

1) 池内幸司，越智繁雄，安田吾郎，岡村次郎，青野正 志 : 大規模浸水時における地下鉄等の浸水想定と被害 軽減方策の効果分析，土木学会論文集 B1（水工学）, Vol.68, No.3, pp136-147, 2012.

2) 関根正人, 関根貴広: 東京都心部の地下空間への 汇濫水の流入危険度とトンネル内の浸水域拡大過 程に関する検討, 土木学会論文集 B1（水工 学) ,Vol.72, No.4, I_1369-I_1374, 2016.

3)岡部良治, 寺田光宏, 土井崚平, 石垣泰輔 : 外水汇濫 における地下鉄軌道を伝播寸る汇濫水の挙動予測に関 する検討, 土木学会第 71 回年次学術講演会, II-116, 2015.

4) 武田誠, 島田嘉樹, 川池健司, 松尾直規 : 庄内川の想 定破堤汇濫による地下空間への流入水量の検討, 第 20 回地下空間シンポジウム, pp155-164, 2015.

5) 武田 誠・西田貢士郎・村瀬将隆・川池健司・松尾直 規 : 地下鉄を考慮した都市の浸水解析, 第 21 回地下空 間シンポジウム, 2016.

\title{
LARGE SCALE INUNDAITON ANALYSIS IN CONSIDERATION OF THE WATER BEHAVIOUR OF SUBWAY LINE IN NAGOYA AND OSAKA
}

\author{
Masataka MURASE, Yusuke NAKAJIMA, Makoto TAKEDA, Kenji KAWAIKE \\ and Naoki MATSUO
}

The flood disaster occurred in the Shounai River basin, JAPAN, due to the heavy rain of typhoon 15, 2012. As the water level of the Shounai River was very high, evacuation information was issued to $1,000,000$ citizens of Nagoya city. The serious hazard may occur in the case of the dike break. A lot of underground space (subway, underground center, etc.) exist in Nagoya city region and Osaka city region. The underground space has the brittleness of water disaster. Nishida and Takeda et al developed the inundation analysis model of urban area in consideration of the water behavior of the subway line. In this stdy, it was to clarify the features of urban inundation by applying the model of Nishida and Takeda et al. in Nagoya and Osaka. From analysis results, the features of the inundation of Nagoya and Osaka was clearly showm. Moreover, it was also shown the risk of Osaka from the view point of the underground inundation. 